\title{
The ethics of the penultimate in a situation of ambiguity: A possible and relevant interpretation of Bonhoeffer in Brazil today
}

\author{
Von Sinner, R \\ Stellenbosch University \\ r.vonsinner@est.edu.br
}

\begin{abstract}
This article explores Bonhoeffer's ethics of the penultimate in view of his poem "Christians and heathens" in dialogue with the Brazilian movie "God is Brazilian", a picture of reality in North-eastern Brazil with all its ambiguities, including religious ambiguities. While religion seeks God's help and in one way or another receives it, the real difference between Christians and heathens is that the former stand by God in God's suffering as represented in human suffering. Bonhoeffer realized that in the penultimate there cannot be purity in real life. Latin American theologians Rubem Alves and Jon Sobrino, among others, followed the same line. For them as for Bonhoeffer, God is not a deus ex machina to fill in the gaps left by humans, but a God who is effective right in the centre and indeed the entirety of life. God is, then, present right in the midst of the ambiguities of life, in clear contrast with contemporary tendencies to shun such ambiguity.
\end{abstract}

Key words

Dietrich Bonhoeffer; Public Theology; ambiguity; Neopentecostalism 
Only the suffering God can help.

Dietrich Bonhoeffer ${ }^{1}$

ultra equinoxialem non peccavit.

Caspar Barlaeus ${ }^{2}$

\section{Introduction}

My first contact with Bonhoeffer was when I read Nachfolge (Discipleship) ${ }^{3}$ as a Swiss teenager in 1983. I was fascinated, but also frightened by it. At the time, our evangelical youth fellowship in the Basel Reformed Church used to read passages from Thomas a Kempis' Imitatio Christi ${ }^{4}$ and of Bonhoeffer's book and had the idea that we were now among the true followers of Christ, of course much more than anybody around us. While such naïve arrogance - as I would call it in hindsight - inflated our chests, it also burdened our hearts, and to be liberated from such burden also meant to leave, for some time, the "Discipleship" aside. Bonhoeffer himself admitted in his "Ethics" in a Letter to Eberhard Bethge of 21 July, 1944, that "I thought I myself could learn to have faith by trying to live something like a saintly life. I suppose I wrote Discipleship at the end of this path. Today I clearly see the dangers of the book, though I still stand by it." 5 Note that Bonhoeffer did not discard his earlier work - "I still stand by it". But he saw dangers, and such dangers, according to Schmitz, are "nothing but the resolve to remain pure from guilt, no matter what evil is loose in the world

1 Dietrich Bonhoeffer, Letters and Papers from Prison, DBWE vol. 8, ed. Eberhard Bethge (Minneapolis: Fortress Press, 2010), 479-80; this affirmation has found prominent reception in Latin America, cf. Elsa Tamez, The Amnesty of Grace. Justification by Faith from a Latin American Perspective (Nashville: Abingdon, 1993) and the works of Jon Sobrino, on these see Sturla J. Stålsett, The crucified and the Crucified. A Study in Liberation Christology of Jon Sobrino (Bern: Peter Lang, 2003), 393, 430.

2 Barlaeus wrote this famous aphorism in his book Rerum per octennium in Brasilia (Amsterdam, 1647, as quoted in Urs Bitterli, Die 'Wilden' und die 'Zivilisierten'. Grundzüge einer Geistes- und Kulturgeschichte der europäisch-überseeischen Begegnung [1976], $2^{\text {nd }}$ ed. [München: C.H. Beck, 1991], 246), written at the request of Maurice of Nassau-Siegen, after the latter's return from Brazil.

3 Dietrich Bonhoeffer, Nachfolge [1937], mit einem Nachwort von Eberhard Bethge, $12^{\text {th }}$ ed. (München: Kaiser, 1981).

4 Thomas a Kempis, The Imitation of Christ [1418-27] (Peabody: Hendrickson Publishers, 2004).

5 DBWE 8, 486. 
and demands a decision on behalf of the oppressed." Bonhoeffer wrote his letter a day after the attempt to kill Hitler of which he knew and which he approved, a decision and attitude that would cost him his life. It was no longer possible to remain pure and not to become guilty. At the same time, Discipleship is about much more than juvenile moral rigor that can make oneself feel superior to others. It is about responsibility for one's and other's life in the world.

Bonhoeffers' Letters and Papers from Prison, however, were liberating for us, precisely from such misunderstanding of Discipleship. Another Bonhoeffer came for us to the fore: Bonhoeffer the human being of flesh and blood, Bonhoeffer the martyr, Bonhoeffer the poet. That our saint would appreciate smoking and even contemplate in awe a cigar Karl Barth had sent to him, saying it was "a really ineffable reality [eine wirklich unbeschreibliche Realität]" ${ }^{7}$, came as a shock to our youth fellowship with its rigid morality. Rather than declaring our saint bound towards hell as we well might have done, however, we started to understand there was a deeper sense to be found in the saintliness of sinners. As Leonardo Boff would put it, this cigar became a "sacrament", a highly meaningful symbol of friendship and of a freedom that in its own way illuminated Bonhoeffer's cell in that moment. ${ }^{8}$

6 Florian Schmitz, Reading Discipleship and Ethics Together: Implications for Ethics and Public Life, in: Clifford J. Green and Guy C. Carter, eds., Interpreting Bonhoeffer: Historical Perspectives - Emerging Issues (Minneapolis: Fortress, 2013), 147-153, 152.

7 Dietrich Bonhoeffer, Widerstand und Ergebung. Briefe und Aufzeichnungen aus der Haft [1951], herausgegeben von Eberhard Bethge, 12 ${ }^{\text {th }}$ ed. (Gütersloh: Gütersloher Verlagshaus Gerd Mohn, 1983), 81. Letter of 26 November, 1943. Translation mine. Note the title of Brazilian Dominican Friar Frei Betto as he was imprisoned by the military regime: Cartas da Prisão (Rio de Janeiro: Civilização Brasileira, 1985), i.e. Letters from Prison.

8 Leonardo Boff, Sacraments of Life - Life of the Sacraments (Hassalo: Pastoral Press, 1987). Here, he tells the story of a yellowed straw cigarette butt, the last his father had smoked before he passed away, sent to Leonardo as he was in his doctoral studies in Munich and received on August 11, 1965. For him, tis cigarette butt became a symbol, a sacrament. Boff says: "it makes the figure of my father present even now as a familiar archetype of values whom we hold in great esteem. We wrote on his tomb: 'We heard from his mouth, we learned from his life: he who does not live to serve, does not live worthily." http://www.leonardoboff.com/site-eng/vista/2002-03/dec19.htm, accessed on 9 April, 2016. 
One of the poems that most caught my attention already at the time - and again and again since - was "Christian and Heathen":

People go to God when they're in need, plead for help, pray for blessing and bread, for rescue from their sickness, guilt and death. So do they all, all of them, Christians and heathens.

People go to God when God's in need, Find God poor, reviled, without shelter or bread, See God devoured by sin, weakness and death.

Christians stand by God in God's own pain.

God goes to all people in their need, Fills body and soul with God's own bread, goes for Christians and heathens in Calvary's death and forgives them both. ${ }^{9}$

This poem also challenged our youth fellowship position, as we far too much thought we knew who would be saved (us among them, of course) and who would go to hell. Contrary to this and, for us, surprisingly, the first and last stanza stress the "all". All pray to God to have him help them in their need. They are calling for the deus ex machina that would instantly help them. And God does help them all, forgiving Christians and heathens. Christians, however, distinguish themselves from heathens as those who stand by God when God is in need. In the already mentioned letter to Eberhard Bethge of 21 July, 1944, Bonhoeffer says that it is important to live a "profound this-wordliness" as a characteristic of Christianity: "By this-worldliness I mean living unreservedly in life's duties, problems, successes and failures, experiences and perplexities. In so doing we throw ourselves completely into the arms of God, taking seriously, not our own sufferings, but those of God in the world - watching with Christ in Gethsemane." This is, for Bonhoeffer, faith, and metanoia, making people human and Christian. For him, the Christian "is not a homo religiosus, but simply a human being", characterized by "profound this-worldliness" through discipline and in view

9 Bonhoeffer, D, Letters and Papers from Prison (Dietrich Bonhoeffer Works, Volume 8) (Minneapolis: Fortress Press, 2010), 485. 
of death and resurrection. ${ }^{10}$ This is what it means to stand by God in God's need. The "heathen", for their part, are less non-believers than in a common sense "religious" people, precisely of that religion Bonhoeffer sees the need of being freed in a "non-religious" Christianity. "It is not the religious act that makes the Christian, but participation in the sufferings of God in the secular life. That is metanoia: not in the first place thinking about one's own needs, problems, sins, and fears, but allowing oneself to be caught up into the way of Jesus Christ, into the messianic event, thus fulfilling Is. 53."11

For Bonhoeffer the decisive question was "who is Christ actually for us today?", ${ }^{12}$ also a central issue for Liberation Theology has been "Who is Christ" and "Who is God" for us today, or else, which Christ, which God do we believe in? In Bonhoeffer's time, the choice to be made was: Is it the God of the German Christians which condoned the Nazi regime and its practices of systematic destruction of Jews as well as communists, homosexuals, people with disabilities and others deemed unworthy to live in an Arian society? Or is it the God that died with the victims in the concentration camp, as told prominently by Elie Wiesel? ${ }^{13}$ We can see a certain dislocation of the question not so much as to a dogmatic or metaphysical answer on "how" or "that" God is, but to the question of "where" God is, on whose side, of the oppressor or the oppressed, of the suffering or the powerful. The latter question resounds with the discussion in Latin America, with Sobrino's call for an answer: "Where is God?"14 And it also resounds, obviously, with the South African context. ${ }^{15}$

10 Quoted according to http://www.onbeing.org/program/ethics-and-will-god-legacydietrich-bonhoeffer/ feature/letter-eberhard-bethge-reflections, accessed on 07 May 2016.

11 Bonhoeffer, Letters and Papers from Prison, 362, as quoted by John De Gruchy, "Oppressive Suffering, Theological Reflection, and Christian Solidarity", in: Theology and Ministry in Context and Crisis. A South African Perspective (Grand Rapids: Eerdmans, 1986), 96-124, 119.

12 DBWE 8, 362.

13 Elie Wiesel, Die Nacht. Roman (Freiburg: Herder, 1996), cf. Hans-Joachim Sander, Einführung in die Gotteslehre (Darmstadt: Wissenschaftliche Buchgesellschaft, 2006), 162 .

14 Jon Sobrino, Where is God? Earthquake, Terrorism, Barbarity and Hope (Maryknoll: Orbis, 2004)

15 See De Gruchy, “Oppressive Suffering”, esp. 107. 
In the movie "God is Brazilian", which is available in a version with English subtitles and which I recommend for a quite faithful picture of Brazilian North-eastern reality, being portrayed with a twinkling eye, we have a quite similar message. The context is much less dramatic than was Bonhoeffer's, and yet suffering abounds in various forms in that reality where precariousness and death are, for many, a daily experience. ${ }^{16}$ Let me briefly summarize its plot. God wants to take leave because he is sick of all the pleas and petitions people constantly direct towards him. "People go to God in their need", all of them, Christian and heathen, as writes Bonhoeffer. So "he", God represented by the famous actor Antonio Fagundes, appears in North-eastern Brazil to look for somebody to substitute him during his holidays. There are many candidates, but none of them is adequate. The most adequate is a white man who made the decision to live among indigenous people, in solidarity. God eventually finds him and asks him to assume office, but that one doesn't want to substitute God under any circumstances - he is a confessed and convinced atheist. God can do whatever miracle he wants, and in the movie he indeed does some things to impress the desired substitute - with no success whatsoever. Consequently, God has to resume office. No holidays. The interesting message is that the person that most stands by God in his engagement is not among those who "plead for help, ask for happiness and bread", to quote Bonhoeffer again, but has renounced that because he believes religion is oppressing rather than liberating. God sees what he does and commends him for it. A "heathen" person, as it were, is more Christian than all the Christians that appear in the movie. Indeed, the name of the story on which the movie is based is called "The Saint that didn't believe in God".

It was not least this very same poem by Bonhoeffer that inspired Jesuit theologian Jon Sobrino. Sobrino wrote several books on Christology in a Latin American context and connected the people he perceived as the crucified people with the Crucified, Jesus Christ, especially after the 1989 slaughter of six of his fellow Jesuits, their housekeeper and her daughter. ${ }^{17}$

16 God is Brazilian, directed by Carlos Diegues based on the Novel by João Ubaldo Ribeiro, O Santo que não acreditava em Deus, published in 1991 (http://www.releituras.com/ joaoubaldo_osanto.asp, accessed on 10 April, 2016), Colour Movie, 110 minutes, Brazil 2003.

17 See especially Jon Sobrino, Jesus the Liberator. A Historical-Theological Reading of Jesus of Nazareth (Maryknoll, Orbis, 1993); Stålsett, The crucified; Érico João Hammes, 
Because of their theology of liberation and critique of the military government, the army killed them in their house. Sobrino, who was travelling and therefore escaped the attack, was profoundly shaken. A copy of Jürgen Moltmann's “The Crucified God” was found lying next to one of the dead..$^{18}$ Sobrino insisted, as did Bonhoeffer, that only a suffering God can help. In his more recent book on theodicy, Sobrino writes: "God, nailed to the cross, allows that they expel him from the world. God is powerless and weak in the world, and only in this way is God with us and helps us. Only a God that suffers can help us". ${ }^{19}$ At the same time, Sobrino warns and this is certainly a contextual interpretation in a new time and a new place - of attributing the first stanza to human hybris. Rather, his plea is for taking seriously that humans, and especially poor people, "need all these things". Their plea to God is not for private reasons and interests, says Sobrino, but they are "looking for bread and dignity, and who are helped by God to come down from the cross" - which is a different message than the one to the crucifiers. ${ }^{20}$

It is, indeed, not an abstract knowledge of God that is needed, but an attitude in relation to God following God's own attitude in Christ crucified, which is an attitude pro me. Christians are those, as Bonhoeffer writes in his poem, who stand by God in his suffering, which is precisely the suffering of the "poor, reviled, without shelter or bread", those who see "God devoured by sin, weakness and death". The great judgment in Matthew 25 comes to mind: "Truly I tell you, just as you did it to one of the least of these who are members of my family, you did it to me" (Mt 25:40). It is vicarious suffering. "Suffering becomes redemptive when it is vicarious", says John De Gruchy. "In this act of solidarity we meet God and discover not only where God is but also who God is." ${ }^{21}$ It is compassionate action that distinguishes

“Cristologia e seguimento em Dietrich Bonhoeffer". Teocomunicação, 21/94 (1991), 497 515.

18 As Jürgen Moltmann recalls in Erfahrungen theologischen Denkens: Wege und Formen christlicher Theologie (Gütersloh: Kaiser/Gütersloher Verlagshaus, 1999), 197.

19 Translation mine from Jon Sobrino, Onde está Deus? Terremoto, terrorismo, barbárie e utopia (São Leopoldo: Sinodal, 2007), p. 195. English version see above, note 14. Sobrino quotes from the Letters and Papers from Prison.

20 Translation mine from Jon Sobrino, Christologie der Befreiung (Mainz: Grünewald, 2008), 342.

21 De Gruchy, "Oppressive Suffering”, 119. 
Christian from heathen, not their "religious" relationship to God nor God's love for all of them. An existential involvement with God is required from God's revelation in the person who suffers. "To be touched by the revelation of God provokes a new attitude in relation to Him which is mediated in a special manner by the real cross of the oppressed", says Brazilian Lutheran theologian Nélio Schneider, a fine translator of Bonhoeffer into Brazilian Portuguese. ${ }^{22}$ It is, therefore, costly grace, as Bonhoeffer famously describes in Discipleship.

Bonhoeffer, thus, inverted the logic: what is really important is what Christians do for God, as represented in those who suffer, this is what distinguishes them from the heathen - and not their calling for God nor God's love for them which exists both for Christians and heathen. God listens and does not take holidays, God attends and does not reject the heathen. This bounces common ideas of clear distinctions into those saved and those not saved, and in fact deviates the gaze from individual salvation to real solidarity. It is there that it becomes clear once more in Bonhoeffer's life and thinking that this is not a Deus ex machina, a God to fill in the gaps left by humans, but a God who is effective right in the centre and indeed the entirety of life. If that is so, this means God is present right in the midst of the ambiguities of life, in a clear contrast with all too many tendencies to shun such ambiguity.

\section{Ambiguity in the Brazilian context}

I would now like to expand further on what I mean by ambiguity in the Brazilian context. Rubem Alves, in his classic "Protestantism and Repression"23 describes and criticizes what he calls "Right Doctrine Protestantism" (protestantismo da reta doutrina), a rigid or thodoxy imposed on the believers and controlled by a variety of disciplinary mechanisms. Purity is sought in doctrine and behaviour, while correct behaviour is linked mainly to sexual behaviour, and all that has connotations of an uncontrolled living of impulses, like drinking alcohol, dancing, and theatre, among others. This is in direct contrast to what is perceived as Brazilian

22 Translation mine from Nélio Schneider, "Sinais da Teologia e do Testemunho de Dietrich Bonhoeffer na América Latina”, Estudos Teológicos 35/3 (1995), 221-257, 250.

23 Rubem Alves, Protestantism and Repression (London: SCM, 1979). 
culture, where sensuality and sexuality, dancing, music, performance are important elements. ${ }^{24}$ There is always a certain ambiguity and simultaneity implied, escaping any final definition. ${ }^{25}$ Even in religion, there is, for many, an ambiguity in that they belong to a specific confession, but seek other religions and their representatives when they feel it might help them better. What Right Doctrine Protestantism wants to avoid is precisely a way of life profoundly rooted in reality, creating its own and specific counter-cultural and, of course, unambiguous reality, where all things are clear. It also means that such position imposes its own specific perspective on the whole of reality, without any openness to dialogue, sharing and being challenged.

Such attempt to establish purity is not so recent in Brazil. As Brazilian anthropologist Ronaldo Vainfas shows, based on a thorough analysis of the minutes of the Inquisition, Jesuits struggled, at the time in the spirit of contemporary European Counter-Reformation, "against the advance of "Lutheranism" on the peninsula, be it real or chimerical [...], [and] on the purification of popular mentalities, the demonization of religious syncretism, the persecution of "moral offenses" to the family and the "abhorrent heretical longings"." 26 A century later, during the Dutch occupation of a considerable coastal line in Pernambuco in North-eastern Brazil, theologian, philosopher and historian Caspar Barlaeus (1584-1648) quoted a famous aphorism that depicts well what the conquerors thought about the new world: ultra equinoxialem non peccavi, a kind of eviction of penitence for the not always so pure and correct Dutch occupants: "Below the equator, I have not sinned", i.e. I cannot have sinned because there is no sin there. In my colleague Vítor Westhelle's interpretation, this means that the New World was at the same time paradise and hell, where neither sin nor redemption were possible. ${ }^{27}$ This implied, however, two standards: the ambiguity the Europeans reserved for themselves was denied to the natives

24 See, for instance, Richard Parker, Bodies, Pleasures, and Passions. Sexual Culture in Contemporary Brazil (Nashville, Tn.: Vanderbilt University Press, 2009).

25 See André S. Musskopf, Via(da)gens teológicas. Itinerários para uma teologia queer no Brasil (São Paulo: Fonte Editorial, 2012), 35-166.

26 Ronaldo Vainfas, Trópicos dos pecados: moral, sexualidade e inquisição no Brasil (Rio de Janeiro: Campus, 1989), 190.

27 Vítor Westhelle, "O tamanho do paraíso: pressupostos do conceito de pecado na teologia latino-americana”, Estudos Teológicos 38/3 (1998), 239-51, 242; After Heresy. Colonial Practice and Post-Colonial Theologies (Eugene, Or.: Cascade, 2010), 33-39. 
of the New World. They were seen either as closer to paradise or closer to hell, as the conquistadores pleased, and treated accordingly. ${ }^{28}$

There is a continuous ambiguity in life, as expressed in Lutheran theology by the simul iustus et peccator. ${ }^{29}$ This is not meant to excuse responsibility for wrongdoing. On the level of human practice, there is sin as different from just action, and should be denounced as such. Responsibility for poverty and oppression is not evenly distributed. What is, however, common is the living under the power of sin, which creates an inescapable situation, with structural elements as Liberation Theology has always been insisting. Christians know about this situation brought about by Adam, the first human, and from there have, as I would call it, a "confessional" mistrust in themselves and others, inasmuch as all, including the believers, are subject to the power of sin.

In Neo-Pentecostalism's prosperity gospel, common in Brazil and also in South Africa, and indeed spreading out also to classical Pentecostalism, as well as to historical churches, God becomes the object of requirements. This is another attempt to overcome the deep ambiguity in life, with believers trusting too much their religious leaders, as well as their own faith, and their contributions linked to it. This can lead to disastrous situations, and even to lawsuits: disappointed frequenters want their money back because they alleged they had been induced to pay a large sum of money by being promised their situation would improve, but not attended in their plea. ${ }^{30}$ This is, then, a broken contract, nothing less. While classical Pentecostalism was commonly accused of looking beyond this world to

28 See Stephen Greenblatt, Marvellous Possessions. The Wonders of the New World (Chicago: University of Chicago Press, 1992); Tzvetan Todorov, The Conquest of America. The Question of the Other, revised edition (Norman: University of Oklahoma Press, 1999).

29 See Luther's lectures on Romans, here on Romans 4:7, LW 25:260: "Now, is he perfectly righteous? No, for he is a the same time both a sinner and a righteous man; a sinner in fact [in re], but a righteous man by the sure imputation and promise of God that $\mathrm{He}$ will continue to deliver him from sin until He has completely cured him. And thus he is entirely healthy in hope [in spe], but in fact he is still a sinner; but he has the beginning of righteousness, so that he continues more and more always to seek it, yet he realizes that he is always unrighteous."

30 See, for instance, the following case in which such a lawsuit was won in the second instance, http://oglobo.globo.com/sp/mat/2007/09/10/297664069.asp (accessed on $2 / 21 / 2008)$. 
the coming Kingdom, and to forget about the importance of today in a millennial worldview, this is now exactly the opposite: an accentuated immediatism, which, ultimately, wants to utilize God for felicity on earth, even if tamed by a number of behavioural rules. It gives the idea that, today, you can indeed "stop suffering", and that suffering is not intrinsic to life, but an accident due to evil spirits which have to be exorcised. And such spirits are invariably seen as having come from Africa. ${ }^{31}$

In such a prosperity theology, there is a total abandonment of eschatology. Even the IURD's motto, "Stop Suffering", indicates an immediatist view: now itself your life is to change, now you are to be liberated from all that holds you back from success, now you have to be healed, now you have to become victorious and get the blessings to which you are entitled. This is the message. To the contrary of much of classical Pentecostalism, which tends to be pre-millennial, expecting Christ to return soon and put things in order, establishing his reign of 1000 years (Revelation 20), and thus to put little faith in transformation here and now, the IURD preaches precisely this: transformation here and now. "God's Kingdom is today", says IURD Pastor Paulo De Velasco. ${ }^{32}$ Again, the longing for a concrete transformation of life, for an end to poverty is more than legitimate. Liberation theology also preached it, and also thought that the Kingdom of God was to be realized in a "Christo-finalized" history, even if always under an eschatological reserve. ${ }^{33}$ Still, the emphasis remains on God's free gift, and that the Kingdom of God is not to be confounded with a human utopia. Not to observe such eschatological reserve is to open doors

31 "According to Brazilian Pentecostal pastors, the root of all evil is in Africa, because the religions of African slaves that were sent [sic!] to Brazil in the past form the basis of all kinds of African Brazilian cults [...] It is this evil which travelled with the slaves that they came to combat in Africa"; my translation from Linda van de Kamp, "Pentecostalismo brasileiro, 'macumba' e mulheres urbanas em Moçambique”, in Ari Pedro Oro, Carlos Alberto Steil and João Rickli, eds., Transnacionalização religiosa; fluxos e redes (São Paulo: Terceiro Nome, 2012), 63; see also Rudolf von Sinner, “'Struggling with Africa': Theology of Prosperity in and from Brazil”, in: Andreas Heuser, ed., Pastures of Plenty: Tracing Religio-Scapes of Prosperity Theologies in Africa and Beyond (Frankfurt: Peter Lang, 2015), 117-130, of which I freely make use in this section.

32 As quoted by Ricardo Mariano, Neopentecostais: Sociologia do novo pentecostalismo no Brasil (São Paulo: Loyola, 1999), 147.

33 See Gustavo Gutiérrez, A Theology of Liberation: History, Politics, and Salvation (Maryknoll: Orbis, 2006), especially 82-140. 
to confuse God and human beings and, thus, to make human beings gods. Some representatives of a theology of prosperity have indeed claimed precisely that: according to Edir Macedo's brother-in-law Romildo Ribeiro Soares, leader of the Neopentecostal International Church of Grace "the believer has to act, to operate, as if he were a god"; others outrightly state that "you are God" (K. Copeland). ${ }^{34}$ It, then, accommodates human being completely within capitalism, without any critical distance. A God equal to humans, or subject to humans equal to Godself, cannot provide any critique of the reign of Mammon (cf. Lk 16:13).

It is important, against such forced disambiguation, to stress that the world has both good and bad elements, which are and remain mixed, as the parable of the weed among the whet shows so well (Mt 13:24-30). ${ }^{35}$ The world in which we live is ambiguous, and we cannot escape this situation, neither by trying to be pure, nor by trying to free the world from all evil by exorcism. Both attitudes are theologically highly questionable, but beyond this also make tolerance and the acceptance of pluralism, namely religious pluralism, virtually impossible. Where there is no deus absconditus, no mysterious God who surpasses our understanding and is never reducible to our perception and logic, but rather a God controlled by humans, perfectly known in his features to those who believe in him, pluralism is a theoretical impossibility and practical danger to be combated.

John R. Stumme highlights that "the ethics of the two kingdoms is an ethics of realism." ${ }^{36}$ It implies, thus, a sober analysis and judgment, acknowledging the power of evil and its appearance in human will and social and political structures. The conscience of the ambiguous character of all decisions and "historical projects," as underlined by Stumme, remembers the importance of an eschatological reserve: No historical project can represent the Kingdom of God, nor any existing situation. While ultimately recognized by all, the applicability of this principle, i.e., the degree to which human

34 As quoted by Mariano, Neopentecostais, 155.

35 The dangers of dualisms in a theologically undergirded Brazilian theocracy and messianism (of the dominating and the dominated, respectively) become evident in philosopher Marilena Chauí's book on Brazil's “Founding Myth": Brasil: mito fundador e sociedade autoritária (São Paulo: Fundação Perseu Abramo, 2000).

36 John R. Stumme, “Algumas teses sobre os dois reinos", Estudos Teológicos 23/3 (2004), 249-64, 263. 
beings can and are bringing about the Kingdom of God through their actions, has been a matter of debate. Roman Catholic theologians tended to believe more in such realization, and criticized Lutheranism for having a negative anthropology and, thus, promoting a passive attitude towards transformation and a pessimist view on the future. For them, it probably aroused fears of falling back into a double notion of history as preeminent in the Catholic Thomistic tradition of distinguishing between the natural and the supernatural, against which Gutiérrez and others stressed precisely the unity of history. ${ }^{37}$ Lutherans have held against this criticism that theirs was not a pessimistic, but a realistic view of humanity, and that the church "constitutes itself over the forgiven sin, however, it is committed with help and solidarity to the poor. Both are important..." ${ }^{38}$ Lutherans refuse to confuse salvation with human action. There is no human merit as to salvation, which underlines its gratuity and facilitates trust in God through Christ. This, however, does not mean that service does and must not flow from this gift, nor does it underestimate human capacity, as both Luther and Calvin highly valued reason, even the one existing outside the Christian fold. ${ }^{39}$ Love, as such a gift, must seek efficiency, as Brakemeier emphasizes with a reference to Miguez Bonino. ${ }^{40}$

\section{Bonhoeffer and ambiguity - the penultimate and the ultimate}

I now return to Bonhoeffer. My sense is that in relating and putting in tension the penultimate and the ultimate, he helps us to both affirm unequivocal action in the world and enduring a real, ambiguous situation in which there is no escape into a false purity, in which responsible decisions are to be made. This sometimes means to opt for the lesser of two

37 I.e., the unity of profane history and the history of salvation, see especially the chapter "liberation and salvation" in Gustavo Gutiérrez, A Theology of Liberation: History, Politics, and Salvation [1971/1988] (Maryknoll: Orbis, 2006), 83-105.

38 Gottfried Brakemeier, "Pobres e pecadores na ótica de Jesus", Estudos Teológicos 25/1 (1985), 13-63, 58.

39 Cf. Bernhard Lohse, Luthers Theologie in ihrer historischen Entwicklung und in ihrem systematischen Zusammenhang (Göttingen: Vandenhoeck \& Ruprecht, 1995), 214-218.

40 Brakemeier, "Pobres e pecadores", 53; José Miguez Bonino, Doing Theology in a Revolutionary Situation (Philadelphia: Fortress, 1975). 
evils. Both aspects have to accept and affirm that the world is the proper place where Christ is present through his church. "If the ultimate is their justification, the penultimate must be that their condition should be truly human" affirmed the movement Church and Society in Latin America (Igreja e Sociedade na América Latina, ISAL, 1961-73) for which Bonhoeffer was an important reference. ${ }^{41}$

Bonhoeffer affirms that the ultimate is what the Reformation called the justification of the sinner by grace through faith alone. The basis of new life is the life, death and resurrection of Christ, which beyond faith creates love and hope. Justification is the ultimate in a qualitative sense, i.e. there cannot be anything that goes beyond God's mercy. It is the last word also in a sense of time: "It is always preceded by something penultimate, some action, suffering, movement, volition [Wollen], defeat, uprising, entreaty [Bitten] or hope". ${ }^{42}$ Bonhoeffer speaks about two "extreme" solutions that, after all, try to do away with the relation and the tension between the ultimate and the penultimate. In what he calls the "radical" solution, one forgets about the penultimate and only sees the ultimate. In what he calls the solution of "compromise", the penultimate gets its own right and is detached from the ultimate. Although there is some truth in both solutions, only one sees God as Judge and Redeemer, the other only as Creator and Preserver. But in this way, "faith in God is broken apart". Bonhoeffer states: "There is earnestness neither in the idea of a pure Christianity in itself nor in the idea of man [sic] as he is himself; there is earnestness only in the reality of God and the reality of man which became one in Jesus Christ." ${ }^{{ }^{43}}$ All dimensions of Christ have to be held together: Gods love in the incarnation, God's judgement in the crucifixion, and God's will towards a new world in the resurrection. Thus, coherence and tension, fullness and brokenness have to be held together. From there, my Catholic colleague Érico Hammes, affirms: "From freedom of oneself, from "existing for others" until death is born omnipotence, omniscience, omnipresence. To believe in this transcendence means to

41 Júlio de Santa Ana, “The Influence of Bonhoeffer on the Theology of Liberation”, in The Ecumenical Review 27/2 (1976), 188-197, 192-194.

42 Dietrich Bonhoeffer, Ethics. Edited by Eberhard Bethge (London: SCM, 1955), 83.

43 Bonhoeffer, Ethics, 87. 
take part in Jesus' being-for-others, also in suffering." ${ }^{\prime 4}$ Whoever dedicates himself or herself to the ultimate cannot flee from the penultimate. To help us not to flee, but to let ourselves be confronted with concrete situations in everyday life while looking at them in the perspective of God's love, God's judgement and God's will towards a new world is, I believe, a most relevant inspiration we can take from Bonhoeffer's theology in Brazil today.

44 Hammes, “Cristologia”, 504. 